\title{
New records and geographical distribution of Alburnus hohenackeri Kessler, 1870 (Teleostei: Cyprinidae) in Iran
}

\author{
Halimeh Zareian ${ }^{1}$, Hamid Reza Esmaeili ${ }^{1^{*}}$, Ali Gholamhosseini ${ }^{2,3}$ and Golnaz Sayyadzadeh ${ }^{1}$ \\ 1 Shiraz University, Faculty of Sciences, Department of Biology, Shiraz, 71454. Iran. \\ 2 Ferdowsi University of Mashhad, Faculty of Sciences, Department of Biology, Mashhad, Iran. \\ 3 Graduate University of Advanced Technology, Institute of Science and High Technology and Environmental Sciences, Department of Biodiversity, \\ Kerman, Iran. \\ * Correspondence author. E-mail: hresmaeili@yahoo.com
}

\begin{abstract}
The distribution of the Persian bleak, Alburnus hohenackeri Kessler, 1870 in Iran is described. During a survey from 2009 to 2012, we captured 30 specimens of A. hohenackeri from Choghakhor Wetland in Tigris River basin and Kardeh Dam in Harirud River basin of Iran. This is the first report of the occurrence of this species in these localities. The main distribution range in Iran is the southern part of the Caspian Sea from where it has been translocated to the other Iranian basins along with exotic Chinese carps.
\end{abstract}

The bleaks belong to the family Cyprinidae and are found in Europe and the northern parts of Southwest Asia. Based on the works of Bogutskaya (1997), Bogutskaya and Naseka (2004) and Kottelat and Freyhof (2007), the Alburnus and Chalcalburnus genera were merged into a single genus, Alburnus with about 38 species, of which 7 occur in Iran including A. atropatenae Berg, 1925; A. caeruleus Heckel, 1843; A. chalcoides (Güldenstaedt 1772); A. filippii Kessler, 1877; A. hohenackeri Kessler, 1870; A. mossulensis Heckel, 1843 and A. zagrosensis Coad, 2009 (Esmaeili et al. 2010a; Coad 2012).

The Persian bleak (the morvarid mahi, meaning pearl fish), Alburnus hohenackeri Kessler, 1870 is diagnosed from other congeners or from other Alburnus species in Iran by the following characters: origin of the anal fin below $4^{\text {th }}-5^{\text {th }}$ branched dorsal rays; lateral line scales 38 $43+3$; anal fin branched rays 11-161/2; gill rakers 16-25; ventral keel exposed, partly or completely scaled; body deep, depth $25-32 \%$ of standard length, markedly laterally compressed; caudal peduncle depth 1.7-2.1 times in its length (Kottelat and Freyhof 2007). The overall color in life specimens of $A$. hohenackeri specimens is bright silver with the posterior scale margins grey on the upper flank. The back is dark blue to olive or bluish-green and is sharply distinct from the lighter flanks. The mid-line of the back has a narrow dark line. The lateral line and the area above it have some dark pigmentation, concentrated along the lateral line itself, but there is no dark stripe or it is only faintly developed. Above this stripe there is an iridescent golden-green stripe only visible at a certain angle (Coad 2012).

Alburnus hohenackeri was originally described from Karabakh, Azerbaijan, on the Kura River. This taxon in Iran was formerly included within the wide-ranging species, Alburnus alburnus (Linnaeus, 1758) (Esmaeili et al. 2010a; Coad 2012).

The main distribution range of Alburnus hohenackeri, in Iran is the Caspian Sea basin (Aras River to the Atrak River) (Derzhavin 1934; Holčík and Oláh 1992; Kiabi et al. 1999; Abbasi et al. 1999; Abdoli and Naderi 2009), but it was transferred to western, central and eastern Iran including Ab-e Sirvan in the upper Diyala River, Lake Zarivar, Zayandehrud River of Esfahan basin, in Kalshur, Jajarm and Qareh Su of northeastern Dasht-e Kavir basin, and in Hamun-e Kushk, and Kahak and Sistan dams of Sistan basin, and possibly in Minab (= Esteghlal) Dam (Abdoli 2000; Ghorbani Chafi 2000; Esmaeili et al. 2011a). This species is found in open waters of lakes along the shore or in slow rivers, avoiding turbid conditions and heavy vegetation (Coad 2012).

The aim of this work is to describe and map the current distribution of $A$. hohenackeri in Iran with new records from two Iranian inland waters.

The present study is based on previous records and new collections made by the authors using hand net, hook and electro-fishing during different field trips in 2009-2012. Collected specimens were preserved in 10\% formalin in the field and deposited in the Zoological Museum of Shiraz University, Collection of Biology Department (Choghakhor: ZM-CBSU J1190- J1210 and Kardeh Dam: ZM-CBSU Z10001- Z10010). Fishes were identified based on morphological and meristic characters following Coad (2012).

Our sampling results include 30 specimens of $A$. hohenackeri (Figure 1) in two new localities including Choghakhor international wetland (Tigris River basin, $31^{\circ} 55^{\prime} 24.0^{\prime \prime} \mathrm{N}, 50^{\circ} 56^{\prime} 08.0^{\prime \prime}$ E, Alt. 2280m, and Kardeh Dam (Harirud basin, 36 39' 16.05" N, 59 39' 43.55" E, Alt. 1292m) (Figures 2 and 3). The morphological characteristics of collected specimens are given in Tables 1 and 2. Coexisting species with $A$. hohenackeri in two new localities (based on our field work) and previous data are given in Table 3.

The accidental or deliberate introduction of exotic fishes and translocation of native fish species from one drainage system to another is ongoing and due to this the fish fauna of some Iranian basins has changed in recent years (Esmaeili et al. 2010 a,b; Gozlan et al. 2010; Esmaeili and Gholamifard 


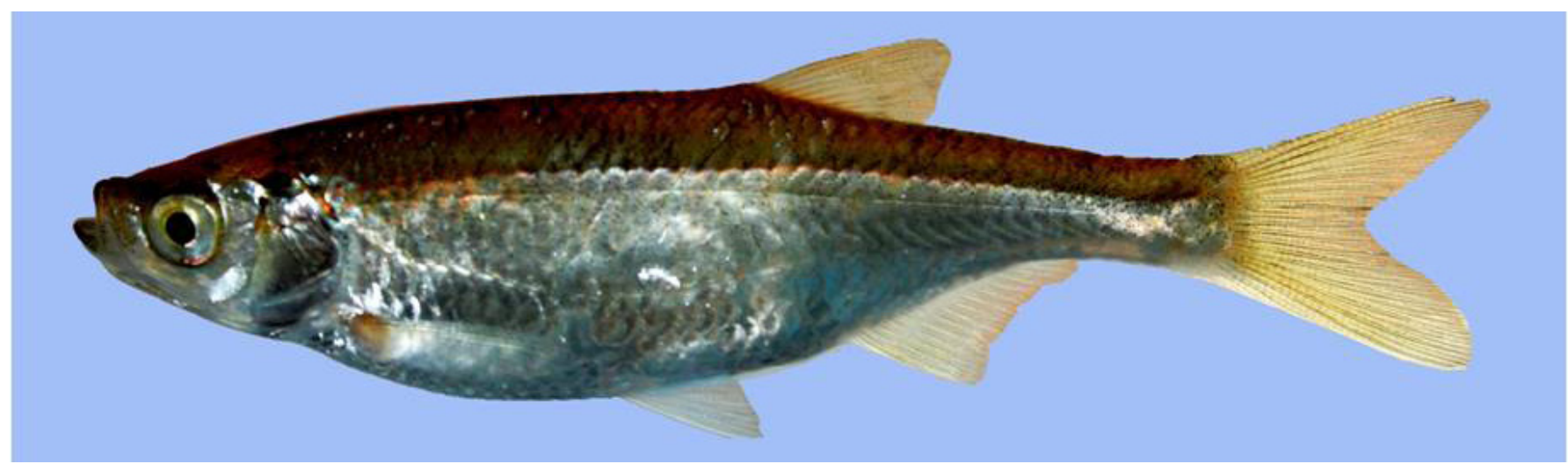

FIGURE 1. Alburnus hohenackeri collected from Choghakhor international wetland.

2011; Esmaeili et al. 2011a,b). These introductions or translocations could be the result of careless release of live specimens from home aquaria, dumping unused bait fish, escapes from nearby aquaculture facilities, the negligent transfer of fertilized eggs of unknown species during stocking, opening connective channels with introduced fish to native habitats, aquaculture, angling, enhancing fish stocks, controlling malaria, research and control of aquatic organisms.

Alburnus hohenackeri occurs in the Iranian Caspian Sea basin and is very likely to have been imported from this area to Choghokhor Wetland and Kardeh Dam along with commercial fish species such as Cyprinus carpio, Hypophthalmichthys molitrix, H. nobilis and Ctenopharyngodon idella. It should also be noted, that the Chinese carps, C. idella, H. molitrix and H. nobilis are found in these water bodies due to yearly restocking, as these species do not spawn naturally in the lake. Young fishes are imported mainly from the Caspian Sea basin. This practice is a permanent open gate for all these alien species to reach into Choghakhor Wetland and Kardeh Dam.

The introduced and translocated fishes may have biological and ecological affects on native fishes through predation, competition, habit changes, genetic changes, behavioral interference (such as direct aggression or disturbance during reproductive activities e.g., courtship, spawning) and introduction of parasites and diseases (Jazdzewski 1980). Records of the monogeneans Dactylogyrus parvus, D. alatus and D. chalcalburni (in fish identified as Alburnus charusini) in Safidrud River (Molnár and Jalali, 1992), Clinostomum complanatum, a parasite causing laryngo-pharyngitis in humans (Shamsi et al. 1997), eye parasites including the digeneans Diplostomum spathaceum and Tylodelphys clavata (Barzegar et al. 2008)

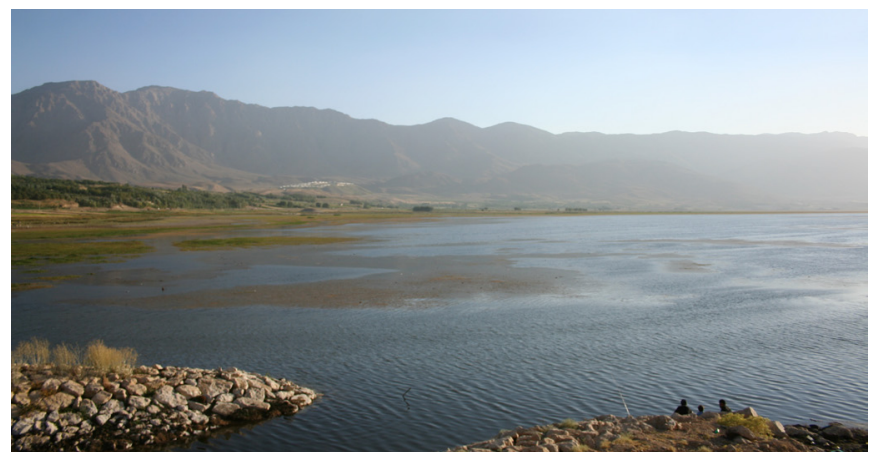

FIGURE 2. Choghakhor international wetland, new collection site for Alburnus hohenackeri. from this fish show its potential risks for other organisms.

A. hohenackeri is very abundant in Kardeh Dam and Choghakhor Wetland and a dominant species of the fish community showing establishment of this fish. Since the introduction and translocation of species is often pointed out as a major factor affecting local fish faunas (Jazdzewski 1980), research groups, and funding environmental agencies are encouraged to devote more resources to the study of interactions between introduced or translocated and local native (endemic) fishes in order to develop evidence-based species-specific impact assessments.

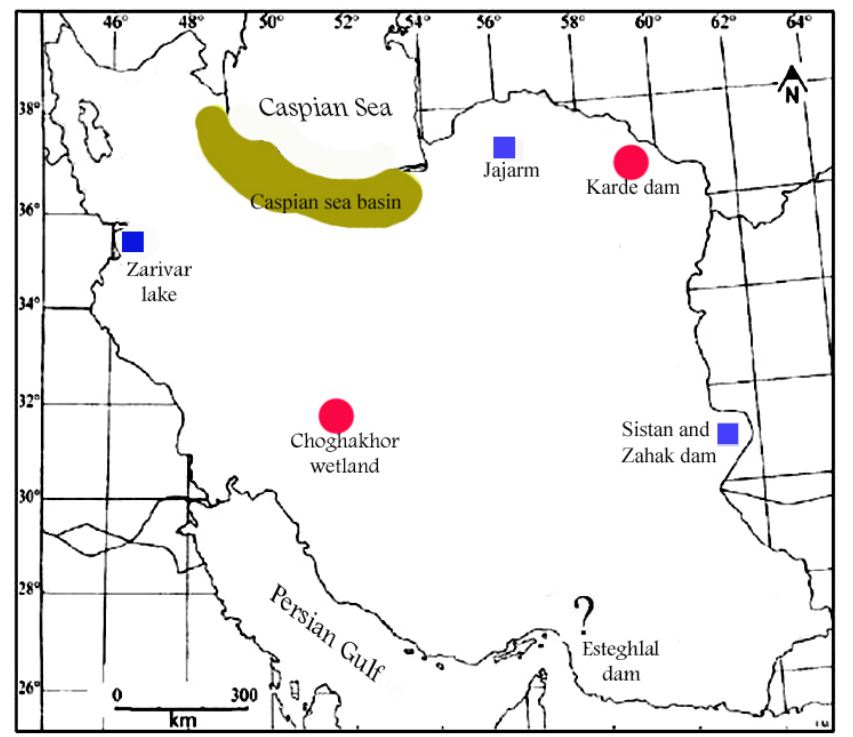

FIGURE 3. Distribution map of Alburnus hohenackeri in Iran; green shaded area: Main distribution range, blue squares: previous translocated localities, and red circles: new translocated localities based on this study.

TABLE 1. Range, mean and standard deviations (data in brackets) of meristic characters of Alburnus hohenackeri in Choghakhor Wetland (20 specimens) and Kardeh Dam (10 specimens) of Iran.

\begin{tabular}{lll}
\hline CHARACTER & $\begin{array}{c}\text { CHOGHAKHOR } \\
\text { WETLAND }\end{array}$ & \multicolumn{1}{c}{ KARDEH DAM } \\
\hline Unbranched dorsal fin rays & $2-3(2.41 \pm 0.50)$ & $3-3(3 \pm 0.00)$ \\
Branched dorsal fin rays & $7-9(7.40 \pm 0.59)$ & $8-9(8.54 \pm 0.52)$ \\
Unbranched anal fin rays & $2-3(2.40 \pm 0.50)$ & $2-3(2.09 \pm 0.30)$ \\
Branched anal fin rays & $11-14(12.86 \pm 0.71)$ & $11-14(12.72 \pm 0.78)$ \\
Lateral line scales & $34-47(40.27 \pm 3.08)$ & $41-45(42.72 \pm 1.27)$ \\
Caudal peduncle scales & $9-12(10.40 \pm 1.09)$ & $10-13(11 \pm 0.77)$ \\
$\begin{array}{l}\text { Number of scales between } \\
\text { dorsal fin and lateral line }\end{array}$ & $7-9(7.42 \pm 0.60)$ & $8-7(7.18 \pm 0.40)$ \\
$\begin{array}{l}\text { Number of scales between } \\
\text { anal fin and lateral line }\end{array}$ & $3-4(3.10 \pm 0.31)$ & $4-4(4 \pm 0.00)$ \\
Gill rakers & $17-24(20.45 \pm 2.08)$ & $16-21(19.30 \pm 1.56)$ \\
\hline
\end{tabular}


TABLE 2. Range, mean and standard deviation (data in brackets) of morphometric characters of Alburnus hohenackeri in Choghakhor Wetland (20 specimens) and Kardeh Dam (10 specimens) of Iran.

\begin{tabular}{|c|c|c|}
\hline CHARACTER & $\begin{array}{c}\text { CHOGHAKHOR } \\
\text { WETLAND }\end{array}$ & KARDEH DAM \\
\hline Total length (mm) & $\begin{array}{c}44.56-71.77 \\
(58.94 \pm 8.44)\end{array}$ & $\begin{array}{c}63.62-82.41 \\
(74.29 \pm 7.14)\end{array}$ \\
\hline Standard length (mm) & $\begin{array}{c}33.81-79.56 \\
(50.20 \pm 12.66)\end{array}$ & $\begin{array}{c}52.57-67.94 \\
(61.05 \pm 5.70)\end{array}$ \\
\hline \multicolumn{3}{|c|}{ In percentage of standard length } \\
\hline Head length & $\begin{array}{c}21.44-28.23 \\
(24.22 \pm 1.46)\end{array}$ & $\begin{array}{l}22.45-24.93 \\
(23.85 \pm 1.0)\end{array}$ \\
\hline Head depth & $\begin{array}{c}15.07-20.97 \\
(17.59 \pm 1.12)\end{array}$ & $\begin{array}{c}18.33-20.17 \\
(19.08 \pm 0.62)\end{array}$ \\
\hline Head width & $\begin{array}{c}9.90-16.41 \\
(11.41 \pm 1.32)\end{array}$ & $\begin{array}{c}10.99-12.19 \\
(11.53 \pm 0.42)\end{array}$ \\
\hline Postorbital length & $\begin{array}{c}9.16-13.96 \\
(11.73 \pm 1.10)\end{array}$ & $\begin{array}{c}10.25-13.25 \\
(12.04 \pm 1.04)\end{array}$ \\
\hline Preorbital length & $\begin{array}{l}5.10-8.08 \\
6.30 \pm 0.79)\end{array}$ & $\begin{array}{c}5.13-7.60 \\
(6.34 \pm 0.74)\end{array}$ \\
\hline Eye diameter & $\begin{array}{c}6.03-8.62 \\
(7.41 \pm 0.72)\end{array}$ & $\begin{array}{c}6.36-7.79 \\
(7.13 \pm 0.43)\end{array}$ \\
\hline Dorsal fin length & $\begin{array}{c}10.16-14.43 \\
(12.14 \pm 1.04)\end{array}$ & $\begin{array}{c}10.90-13.49 \\
(11.95 \pm 0.89)\end{array}$ \\
\hline Dorsal fin depth & $\begin{array}{l}12.41-24.84 \\
(17.52 \pm 4.2)\end{array}$ & $\begin{array}{c}14.25-21.85 \\
(19.29 \pm 2.26)\end{array}$ \\
\hline Predorsal fin length & $\begin{array}{c}28.45-59.45 \\
(54.06 \pm 6.46)\end{array}$ & $\begin{array}{c}55.29-58.21 \\
(56.54 \pm 0.93)\end{array}$ \\
\hline Preventral fin length & $\begin{array}{l}39.71-55.70 \\
(47.46-3.07)\end{array}$ & $\begin{array}{c}44.53-54.85 \\
(49.25 \pm 3.02)\end{array}$ \\
\hline Preanal fin length & $\begin{array}{c}54.37-70.70 \\
(63.61 \pm 3.04)\end{array}$ & $\begin{array}{l}64.22-70.62 \\
(66.61 \pm 2.1)\end{array}$ \\
\hline Anal fin depth & $\begin{array}{c}8.30-18.68 \\
(13.07 \pm 3.42)\end{array}$ & $\begin{array}{c}13.57-16.56 \\
(14.78 \pm 0.96)\end{array}$ \\
\hline Caudal peduncle length & $\begin{array}{c}15.78-23.43 \\
(19.64 \pm 2.12)\end{array}$ & $\begin{array}{c}17.44-20.98 \\
(19.36 \pm 0.96)\end{array}$ \\
\hline Caudal peduncle depth & $\begin{array}{c}8.25-10.31 \\
(9.27 \pm 0.60)\end{array}$ & $\begin{array}{c}8.81-10.98 \\
(10.26 \pm 0.69)\end{array}$ \\
\hline Maximum body depth & $\begin{array}{c}19.19-28.40 \\
(23.67 \pm 2.80)\end{array}$ & $\begin{array}{c}25.95-30.81 \\
(27.81 \pm 1.67)\end{array}$ \\
\hline Mouth width & $\begin{array}{c}4.56-7.03 \\
(6.02 \pm 0.57)\end{array}$ & $\begin{array}{c}5.19-7.00 \\
(5.86 \pm 0.66)\end{array}$ \\
\hline
\end{tabular}

TABLE 3. Coexisting species with Alburnus hohenackeri in Choghakhor Wetland and Kardeh Dam of Iran.

\begin{tabular}{lcc}
\hline SPECIES & $\begin{array}{c}\text { CHOGHAKHOR } \\
\text { WETLAND }\end{array}$ & KARDEH DAM \\
\hline Capoeta damascina & $*$ & $*$ \\
Ctenopharyngodon idella & $*$ & $*$ \\
Cyprinus carpio & $*$ & $*$ \\
Hypophthalmichthys molitrix & $*$ & $*$ \\
Hypophthalmichthys nobilis & $*$ & $*$ \\
Pseudorasbora parva & $*$ & $*$ \\
Gambusia holbrooki & $*$ & $*$ \\
Garra rossica & & \\
Carassius gibelio & $*$ & \\
Alburnus mossulensis & $*$ & \\
Aphanius vladykovi & $*$ & \\
Capoeta aculeata & $*$ & \\
Chondrostoma regium & $*$ & \\
Metaschistura cristata & & \\
\hline
\end{tabular}

ACKNowledgments: We are thankful to A. Gholamifard, R. Zamanian, S. Ghasemian, S. Mirghiasi and B. Parsi for helping in fish collection, B.W. Coad (Canadian Museum of Nature) for his valuable comments on the manuscript and improving the English and Shiraz University for financial support.

\section{Literature Cited}

Abbasi, K., A. Valipour, D. Talebi Haghighi, A. Sarpanah and Sh. Nezami. 1999. Atlas of Iranian Fishes. Rasht: Gilan Inland Waters. Gilan Fisheries Research Centre. vi + 113 p. (In Farsi).

Abdoli, A. 2000. The Inland Water Fishes of Iran. Tehran: Iranian Museum of Nature and Wildlife. 378 p. (In Farsi).

Abdoli, A. and M. Naderi. 2009. Biodiversity of Fishes of the Southern Basin of the Caspian Sea. Tehran: Abzian Scientific Publication. 237 p. (In Farsi).

Barzegar, M., M. Raeisi, A. Bozorgnia and B. Jalali. 2008. Parasites of eyes of fresh and brackish water fishes in Iran. Iranian Journal of Veterinary Research 9(3): 256-261.

Bogutskaya, N.G. 1997. Contribution to the knowledge of leuciscine fishes of Asia Minor. Part 2. An annotated checklist of leuciscine fishes (Leuciscinae, Cyprinidae) of Turkey with descriptions of a new species and subspecies. Mitteilungen aus dem Hamburgischen Zoologischen Museum und Institut 94: 161-186.

Bogutskaya, N.G. and A.M. Naseka. 2004. Katalog beschelyustnykh $i$ ryb presnykh $i$ solonovatykh vod Rossii c nomenklaturnymi i taksonomicheskimi kommentariyami [Catalogue of Agnathans and Fishes of Fresh and Brackish Waters of Russia with comments on nomenclature and taxonomy]. Moscow: Zoological Institute, Russian Academy of Sciences and KMK Scientific Press Ltd. 389 p.

Coad, B.W. 2012. Freshwater Fishes of Iran. Electronic database accessible at www.briancoad.com. Captured on 20 August 2012.

Derzhavin, A.N. 1934. Presnovodnye ryby yuzhnogo poberezh'ya Kaspiya. Vstuplenie [Freshwater fishes of the southern shore of the Caspian Sea. Introduction]. Trudy Azerbaidzhanskogo Otdeleniya Zakavkazskogo Filiala Akademii Nauk SSSR, Sektor Zoologii 7: 91-126.

Esmaeili, H.R. and A. Gholamifard. 2011. Range extension and translocation for Hemiculter leucisculus (Basilewsky, 1855) (Cyprinidae) in western and northwestern Iran. Journal of Applied Ichthyology 27(6): 1394-1395.

Esmaeili, H.R., B.W. Coad, A. Gholamifard, N. Nazari and A. Teimory. 2010a. Annotated checklist of the freshwater fishes of Iran. Zoosystematica Rossica 19(2): 361-386.

Esmaeili, H.R., A. Gholamifard, A. Teimori, S. Baghbani, and B.W. Coad. 2010b. Xiphophorus hellerii Heckel, 1848 (Cyprinodontiformes, Poeciliidae), a newly introduced fish recorded from natural freshwaters of Iran. Journal of Applied Ichthyology 26(6): 937-939.

Esmaeili, H.R., A. Gholamifard and J. Freyhof. 2011a. Ichthyofauna of Zarivar Lake (Iran) with the first records of Hemiculter leucisculus and Alburnus hohenackeri in the Tigris drainage. Electronic Journal of Ichthyology 7(1): 1-6.

Esmaeili, H.R., N. Nazari, A. Gholamifard, G. Gholamhosseini, A. Teimory and B. W. Coad. 2011b. Range extension and translocation for Rhodeus amarus (Bloch, 1782) (Actinopterygii: Cyprinidae) in northwest Iran. Turkish Journal of Zoology 35(6): 883-886.

Ghorbani Chafi, H. 2000. Identification of different fish species in Koohrang, Bazoft and Zayandeh Rood River in Chahar Mahal-eBakhtiary Province. Iranian Journal of Fisheries Sciences 8(4): 43-56. (In Farsi).

Gozlan, R.E., D. Andreou, T. Asaeda, K. Beyer, R. Bouhadad, D. Burnard, N. Caiola, P. Cakic, V. Djikanovic, H. R. Esmaeili, I. Falka, D. Golicher, A. Harka, G. Jeney, V. Kováč, Y. Musil, A. Nocita, M. Povz, N. Poulet, T. Virbickas, C. Wolter, A.S. Tarkan, E. Tricarico, T. Trichkova, H. Verreycken, A. Witkowski, C. Zhang, I. Zweimueller, J.R. Britton. 2010. Pan-continental invasion of Pseudorasbora parva: towards a better understanding of freshwater fish invasions. Fish and Fisheries 11: 315-340.

Holčík, J. and J. Oláh. 1992. Fish, fisheries and water quality in Anzali Lagoon and its watershed. Report prepared for the project - Anzali Lagoon productivity and fish stock investigations. Rome: Food and Agriculture Organization. UNDP/IRA/ 88/001 Field Document 2. x +109 p.

Jazdzewski, K. 1980. Range extensions of some Gammaridean species in European inland waters caused by human activity. Crustacean 6: 84107.

Kiabi, B., A. Abdoli, and M. Naderi. 1999. Status of the fish fauna in the South Caspian Basin of Iran. Zoology in the Middle East 18: 57-65.

Kottelat, M and J. Freyhof. 2007. Handbook of European Freshwater Fishes. Cornol and Berlin: Kottelat and Freyhof. 646 p.

Molnar, K. and B. Jalali. 1992. Further monogeneans from Iranian freshwater fishes. Acta Veterinaria 40: 55-61.

Shamsi, S., A. Dalimi, and R. Pourgholam. 1997. Study on helminths of big eye kilka, Clupeonella grimmi. Proceedings of the 6th Iranian Biology Conference: 67.

RECEIVED: September 2012

ACCEPTED: June 2013

Published ONLINE: August 2013

EDITORIAL RESPONSIBILITY: Tiago Pinto Carvalho 